Ю.В. Чинченко, к.Т.Н., доц.

\title{
ОСОБЛИВОСТІ СТВОРЕННЯ ТА ФУНКЦІОНУВАННЯ АЕРОДРОМНИХ СИСТЕМ КЕРУВАННЯ БЕЗПЕКОЮ ПОЛЬОТІВ В УКРАЇНІ
}

\author{
Національний авіаційний університет \\ E-mail: jdestiny@ukr.net
}

Подано інформацію про результати наукових досліджень в області концепиії керування безпекою польотів. Розглянуто переваги проактивного підходу до профілактики авіаційних подій та особливості впровадження аеродромних систем керування безпекою польотів.

Information about outcomes of scientific researches in field of the safety management concept is provided, benefits of proactive approach to prevention of accidents and features of implementation of aerodrome safety management systems are considered.

Приведена информация о результатах научных исследований в области концепции управления безопасностью полетов. Рассмотрены преимущества проактивного подхода к профилактике авиационных происшествий и особенности внедрения аэродромных систем управления безопасностью полетов.

\section{Постановка проблеми}

Завдяки прийнятим світовою авіаційною спільнотою заходам з безпеки польотів, за останні 30 років [1]:

- різко зменшено кількість авіаційних подій та інцидентів;

- радикально зменшено кількість відмов авіаційної техніки.

Профілактика негативних авіаційних подій у цивільній авіації України (як і в світі) дотепер грунтувалася на концепції забезпечення безпеки польотів, головним принципом функціонування якої $є$ реагуючий підхід. Суть реагуючого підходу полягає в тому, що система запобігання авіаційним випадкам й інцидентам суворо дотримує нормативні вимоги i впроваджує профілактичні рекомендації, розроблені за результатами розслідування авіаційних подій.

Нова ідеологія передбачає створення системи керування безпекою польотів (СКБП), яка дозволить:

- виявлити фактичні та потенційні загрози безпеці;

- застосовувати заходи, що коректують фактори небезпеки;

- забезпечувати безперервний моніторинг;

- регулярно оцінювати досягнутий рівень безпеки польотів.
Мета роботи - дослідження оптимальних шляхів упровадження аеродромних СКБП в Україні, що побудовані не на очікуванні негативної події, а на виявленні небезпечних факторів в авіаційній системі.

Виявлення небезпечних факторів у профілактиці авіаційних подій отримав назву «проактивний» (див. рисунок).

Проведений аналіз літературних джерел [1-4] дозволяє стверджувати, що проактивний підхід до керування безпекою польотів це принципово новий високоефективний спосіб профілактики негативних авіаційних подій.

Проте впровадження аеродромних СКБП не означає повної відмови від системи забезпечення безпеки польотів, оскільки їі компоненти в зміненому вигляді органічно «вплітаються» в нову структуру [5].

\section{Особливості впровадження аеродромних систем керування безпекою польотів}

У разі впровадження проактивного підходу в керуванні безпекою польотів з'являється принципово новий об'єкт, що визначає:

- зміст профілактичної роботи;

- небезпечні чинники компонентів авіаційної системи, які «передують» помилковим діям і стають їх причинами. 


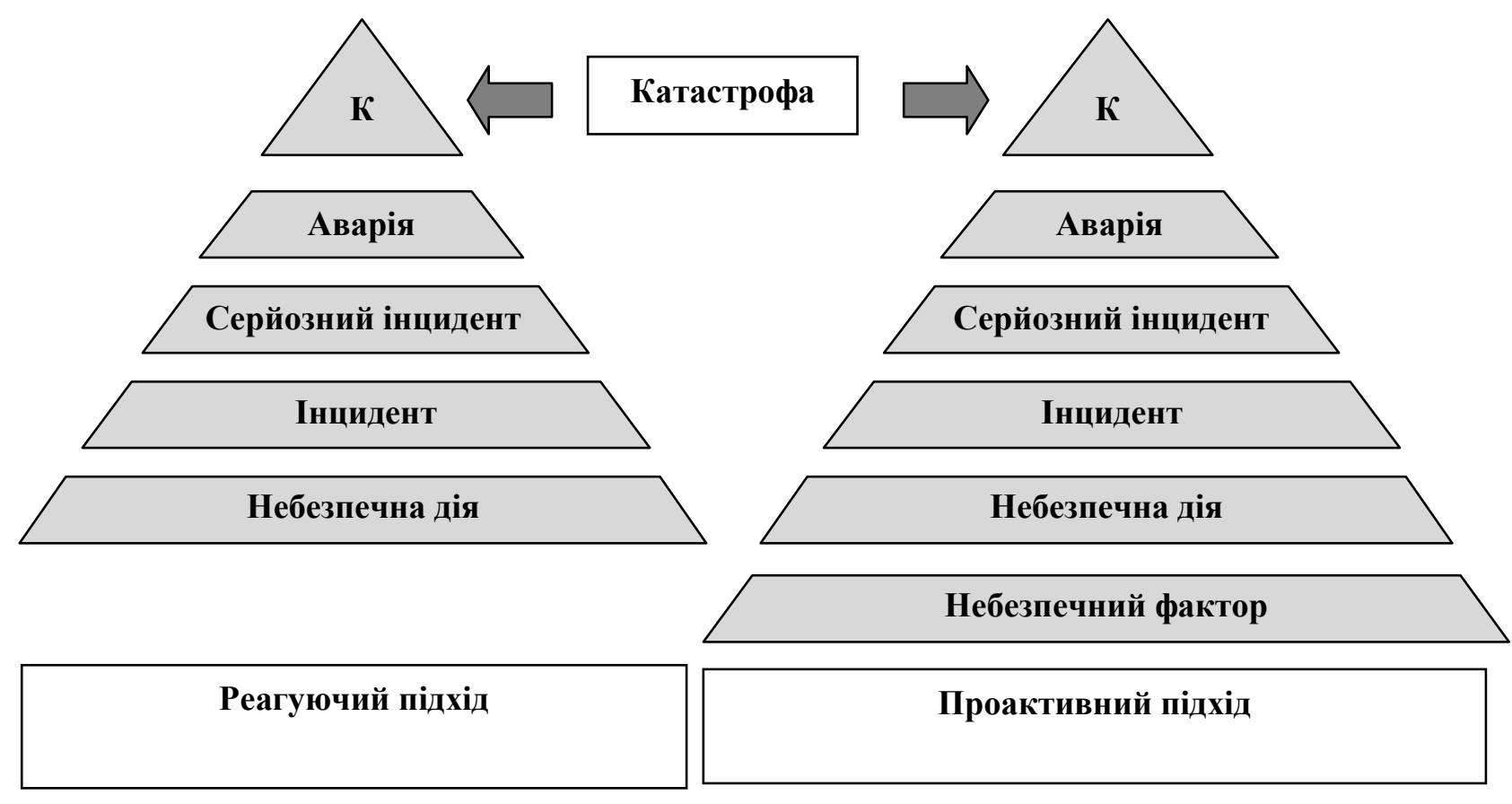

Моделі забезпечення та керування безпекою польотів

Відповідно до проактивного підходу під час керування безпекою польотів акцент робиться на усуненні недоліків компонентів авіаційної системи як ії небезпечних факторів.

Найбільш складними є дві проблеми, які слід вирішувати у разі переходу до керування безпекою польотів [4]:

- проблема усвідомлення персоналом необхідності переходу до керування безпекою польотів (усвідомлення вищим керівництвом не означає усвідомлення персоналом);

- проблема розуміння керівництвом і персоналом доцільності перебудови мислення $\mathrm{i}$ формування нової професійної і корпоративної культури.

Змінювати стереотипи поведінки людини, що застосовуються на основі добре відпрацьованих і закріплених розумових навиків, досить складно. У вирішенні цих питань мають бути задіяні різні інструменти:

- підготовка;

- популяризація;

- виробничі наради.
Упровадження СКБП - досить складний i трудомісткий процес, спрямований, головним чином, на відмову від старих і формування нових стереотипів мислення.

Упровадження СКБП вимагає від керівників усіх рівнів:

- масштабної роз'яснювальної роботи;

- створення в підрозділах «некарального» виробничого середовища;

- впровадження системи добровільних повідомлень.

Упровадження СКБП в авіаційні підприємства докорінно змінює виробничу діяльність, виробничі стосунки, істотно підвищує безпеку польотів та має такі переваги:

- зміщення профілактичної роботи з розроблення рекомендацій за результатами розслідувань на їх запобігання;

- упровадження попереджуючих і прогнозних методів (пошук джерел небезпеки та оцінка ризиків);

- застосування методики системного аналізу причин авіаційних подій;

- створення «некарального» виробничого середовища. 
Упровадження СКБП дозволяє в окремому підрозділі:

- змінити зміст діяльності щодо запобігання авіаційних подій, що концентрується на виявленні небезпечних факторів, оцінці ризиків та їх зниженні;

- підняти на новий рівень відношення «керівник - підлеглий» у проведенні профілактичної роботи та зробити їх «прозорішими» і зрозумілішими;

- підвищити якість і ефективність профілактичної роботи і забезпечити керування нею.

Для окремого фахівця впровадження СКБП дає можливість:

- стати активним учасником виявлення джерел небезпеки у виробничому процесі;

- визначити своє місце в профілактиці авіаційних подій;

- отримати механізм обгрунтування допущеної помилкової дії наявністю небезпечних чинників у системі;

- захистити себе від несправедливого звинувачення;

- удосконалити виробничий процес;

- отримати моральну (матеріальну) винагороду.

\section{Корпоративна культура безпеки в аеронавігаційній системі}

Особливу актуальність питання впровадження аеродромних СКБП в Україні набуло в сучасних умовах у зв'язку з необхідністю:

- розвитку корпоративної культури;

- створення позитивної культури безпеки в авіаційних підприємствах.

Розглянемо практичні питання вдосконалення виробничого середовища авіаційного підприємства та впровадження позитивної культури безпеки.

Корпоративна культура - це потужний інструмент формування висококваліфікованого фахівця.

У виробничій діяльності корпоративна культура визначає межі прийнятної поведінки людини на робочому місці шляхом встановлення поведінкових норм.
Корпоративна культура авіаційного підприємства включає [4]:

- стосунки керівників і підлеглих, фахівців між собою і персоналу різних підрозділів;

- підбір персоналу і його відповідність посаді;

- обмін інформацією і спрямованість іï потоків;

- організацію процесу навчання;

- відношення до помилок і порушень;

- розуміння необхідності впровадження нових технологій, сучасних принципів організації виробництва і підвищення безпеки польотів;

- підготовку документації і стандартів.

Культура безпеки є створюваною керівництвом атмосферою, яка формує:

- відношення співробітників до питань безпеки;

- виробниче середовище до виконання або правильних дій, або порушень.

На проблеми безпеки є три типи реакції авіаційних підприємств, які варіюються від низької культури безпеки, охоплюючи байдужий (бюрократичний) підхід, коли дотримуються лише мінімальні прийнятні вимоги, і до «ідеальної» позитивної культури безпеки (див. таблицю) [3].

Розглянемо етапи формування позитивної культури безпеки персоналу під час впровадження аеродромних СКБП в Україні.

Перший етап - усвідомлення керівниками авіаційного підприємства та підрозділів доцільності впровадження позитивної культури безпеки.

Саме 3 цього етапу починається робота над удосконаленням корпоративної культури. Неприйняття викладеної тези або наявність щонайменшого сумніву в необхідності такого напряму дій робить виконання всіх подальших етапів непотрібним.

У разі успішного подолання першого етапу слід переходити до другого.

Другий етап - обгрунтування цілей, що забезпечують упровадження позитивної культури безпеки:

- упровадження в колективі гостро негативного відношення до порушень; 
Три типа культури безпеки авіаційних підприємств

\begin{tabular}{|c|c|c|c|}
\hline \multirow{2}{*}{$\begin{array}{c}\text { Індикатори } \\
\text { організаційних } \\
\text { процесів }\end{array}$} & \multicolumn{3}{|c|}{ Культура безпеки } \\
\hline & Низька & Бюрократична & Позитивна \\
\hline $\begin{array}{l}\text { Інформація щодо } \\
\text { небезпечних факторів }\end{array}$ & Замовчується & Ігноруються & $\begin{array}{c}\text { Активно } \\
\text { відстежуються }\end{array}$ \\
\hline $\begin{array}{l}\text { Особи, що повідомляють } \\
\text { про небезпечні } \\
\text { фактори }\end{array}$ & $\begin{array}{c}\text { Не підтримуються або } \\
\text { несуть покарання }\end{array}$ & Ігноруються & $\begin{array}{c}\text { Навчають та } \\
\text { заохочують }\end{array}$ \\
\hline $\begin{array}{l}\text { Відповідальність } \\
\text { за безпеку }\end{array}$ & Уникається & Дрібниться на частини & Спільна \\
\hline $\begin{array}{l}\text { Розповсюдження } \\
\text { інформації щодо } \\
\text { небезпечних факторів }\end{array}$ & Не заохочується & $\begin{array}{c}\text { Дозволяється, } \\
\text { але не заохочується }\end{array}$ & Винагороджується \\
\hline 3бої & Приховуються & $\begin{array}{c}\text { Призводить до } \\
\text { локальних рішень }\end{array}$ & $\begin{array}{c}\text { Розслідуються та } \\
\text { спонукають до } \\
\text { реформування системи }\end{array}$ \\
\hline Нові ідеї & Відхиляються & $\begin{array}{c}\text { Розглядаються як } \\
\text { нові проблеми, } \\
\text { а не можливості }\end{array}$ & Заохочуються \\
\hline
\end{tabular}

- створення «некарального» виробничого середовища;

- підвищення значущості й активності персоналу в керуванні безпекою польотів, шляхом системи добровільних повідомлень;

- створення мікроклімату, що сприяє формуванню у персоналу високої відповідальності за свої дії.

Третій етап - визначення і розроблення інструментів, що забезпечують упровадження позитивної культури безпеки:

- культура, що демонструється керівниками при розгляді питань безпеки польотів;

- організація підготовки персоналу з питань керування безпекою польотів;

- популяризація (пропаганда) ключових аспектів упровадження позитивної культури безпеки;

- регулярний аналіз стану позитивної культури безпеки.
Четвертий етап - практична робота 3 упровадження позитивної культури безпеки 3 постійним контролем стану справ.

Доцільно визначити показники, вимір яких дозволить керувати процесом упровадження позитивної культури безпеки. Наприклад, увести облік кількості порушень, добровільних повідомлень тощо.

Великий обсяг робіт покладається на аналітичну (робочу) групу, що створюється в кожному підрозділі в рамках упровадження системи керування безпекою польотів.

Подальший розвиток корпоративної культури та впровадження позитивної культури безпеки дозволяє:

- створити принципово новий образ мислення в персоналу, що відрізняється високою відповідальністю за свої дії, розуміння їх наслідків для безпеки польотів;

- сформувати досконаліші стосунки між керівниками і підлеглими. 


\section{Висновки}

Сучасна ідеологія запобігання негативним авіаційним подіям радикально змінює систему профілактичної роботи. Якщо використовувана раніше ідеологія забезпечення безпеки польотів розглядала як головне джерело інформації для розроблення превентивних заходів результати розслідування авіаційних подій, то ідеологія керування безпекою польотів націлює на регулярну діяльність щодо виявлення небезпечних факторів, а також визначення й оцінку ризиків.

Перехід від реагування на авіаційні події до проактивного підходу істотно скорочує їх імовірність, що є головною метою діяльності авіаційного підприємства.

Важливими компонентами системи керування безпекою польотів є:

- «некаральне» виробниче середовище, що забезпечує активну участь персоналу у виявленні небезпечних факторів виробничого процесу;
- система добровільних повідомлень.

Усе це реалізується в умовах створення позитивної культури безпеки.

\section{Література}

1. Энщиклопедия безопасности авиации / М.С. Кулик, В.П. Харченко, Ю.В. Чинченко и др. - К.: Техніка, 2008. - 1000 с.

2. Безпека авіації / В.П. Бабак, В.П. Харченко, В.О. Максимов та ін. - К.: Техніка, 2004. - 584 c.

3. DOC 9859. Руководство по управлению безопасностью полетов. - Монреаль: ИКАО, 2009. $-318 \mathrm{c}$.

4. Козлов В.В. Безопасность полетов: от обеспечения к управлению / В.В. Козлов. М.: ОАО «Аэрофлот - Росийские авиакомпании», 2010. - 270 c.

5. DOC 9422. Руководство по предотвращению авиационных происшествий. - Монреаль: ICAO, 1998. - 270 с.

Стаття надійшла до редакції 26.10.10. 